\title{
Nest and nest-site reuse within and between breeding seasons by three neotropical flycatchers (Tyrannidae)
}

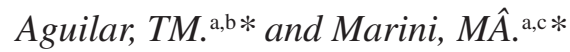

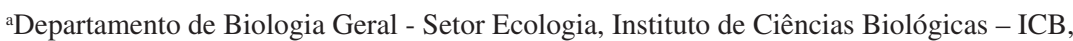 \\ Universidade Federal de Minas Gerais - UFMG, \\ Av. Antônio Carlos, 6627, Campus Pampulha, CEP 31270-901 Belo Horizonte, MG, Brazil \\ bPós-Graduação em Biologia Animal, Instituto de Ciências Biológicas - IB, Universidade de Brasília - UnB, \\ Campus Darcy Ribeiro, Asa Norte, CEP 70910-900 Brasília - DF, Brazil \\ 'Departamento de Zoologia, Instituto de Ciências Biológicas - IB, Universidade de Brasília - UnB, \\ Campus Darcy Ribeiro, Asa Norte, CEP 70910-900, Brasília, DF, Brazil \\ *e-mail: thais_maya@yahoo.com.br,marini@unb.br
}

Received August 22, 2005 - Accepted March 7, 2006 - Distributed August 31, 2007

\begin{abstract}
Nest and/or nest site reuse within and between breeding seasons was reported by the Euler's Flycatcher (Lathrotriccus euleri), the Sepia-capped Flycatcher (Leptopogon amaurocephalus) and the Gray-hooded Flycatcher (Mionectes rufiventris) in forest fragments from southeastern Brazil. Nest and/or nest site reuse between some years was frequent within a single breeding season by the Sepia-capped Flycatcher. Nest reuse, however, was not related to nesting success in the previous breeding attempt. Nest turnover rates (movement to a new site between years) were low for $L$. amaurocephalus, intermediate for L. euleri and high for M. rufiventris.
\end{abstract}

Keywords: Tyrannidae, nest reuse, nest site reuse, nest reuse, neotropical flycatchers, nest site fidelity.

\section{Reutilização do ninho e do sítio de nidificação dentro e entre estações reprodutivas por três espécies de tiranídeos neotropicais (Tyrannidae)}

\begin{abstract}
Resumo
Foram registrados vários eventos de reutilização de ninho ou do sítio de nidificação dentro e entre estações reprodutivas por Lathrotriccus euleri, Leptopogon amaurocephalus e Mionectes rufiventris em fragmentos de floresta do sudeste do Brasil. A reutilização do ninho ou do sítio de nidificação ocorreu entre estes tiranídeos e foi freqüiente dentro de uma única estação reprodutiva para L. amaurocephalus. A reutilização do ninho, contudo, não foi relacionada ao sucesso das tentativas anteriores. As taxas de retorno ao ninho foram baixas para L. amaurocephalus, intermediárias para L. euleri e altas para M. rufiventris.
\end{abstract}

Palavras-chave: Tyrannidae, reutilização de ninho, reutilização do sítio de nidificação, reutilização de ninho, tiranídeos neotropicais, fidelidade ao sítio de nidificação.

\section{Introduction}

For most birds, the nest is only a temporary structure that cannot be reused, not even for the same breeding season. For some species, however, this structure is more permanent and can be used between some years (Barclay, 1988) if it does not disintegrate. Nest site reuse by solitary species is unusual and unrelated to nest type (Curson et al., 1996; Bergin 1997; Friesen et al., 1999). Reuse of a nesting site among years is described as nestsite fidelity (Lindeberg and Sedinger, 1997; Reed et al., 1998; Styrsky, 2005).

The reutilization of old nests may be a consequence of nest site fidelity, of low nest-site availability, or of high quality of these nesting sites. It may also represent a reduction in the energetic cost of building a new nest or a reduction in exposure to predation risks during nest building (Curson et al., 1996; Bergin, 1997; Friesen et al., 1999). Old nests, however, may only be used as substrates to build new nests (Curson et al., 1996; Pichorim et al., 1996; Bergin, 1997; Friesen et al., 1999). Bergin (1997), however, observed that the success of reused nests decreased with the age of the nest, which might be related to the fragility of the nest structure. Moreover, old structures might have higher loads of parasites attacking nestlings, as reported by the Barn Swallow Hirundo rustica, 
which reduced reproductive success due to high parasite infestation (Barclay, 1988).

The purpose of this study is to describe nest and nest site reuse and estimate nest site turnover for three species of flycatchers (Tyrannidae) (Euler's Flycatcher, Lathrotriccus euleri, Sepia-capped Flycatcher, Leptopogon amaurocephalus and the Gray-hooded Flycatcher, Mionectes rufiventris) in secondary forests from southeast Brazil in order to test the hypothesis that nest reuse is dependent on the fate of the former breeding attempt.

\section{Material and Methods}

\subsection{Study site}

Data was collected during a larger study of passerine nest success and biology between August, 1995 and January, 2000 in the Belo Horizonte region (20 00'$20^{\circ} 02^{\prime} \mathrm{S}$ and $43^{\circ} 59^{\prime}-44^{\circ} 00^{\prime} \mathrm{W}$ ), Minas Gerais State, southeastern Brazil. This study was carried out at "Área de Proteção Especial para fins de Preservação do Manancial do Barreiro" owned by the "Companhia de Saneamento de Minas Gerais" (COPASA). The region lies between the Cerrado and the Atlantic Forest biomes, with vegetation consisting of gallery and dry forest fragments embedded in a matrix of various grassland (Cerrado) formations. The flora and avifauna of both biomes can be found in the region. These forest fragments have forests at advanced succession stages ( 150 years). The region has distinct seasonal weather variation with warm rainy summers between October and March and cool dry winters between April and September (CETEC, 1993).

\subsection{Methods}

We searched for nests in the interior of the forest and along streams and dirt roads in three forest fragments, which had areas of 1.8, 50 and 200 ha. Nests found were monitored every 3-5 days until they became inactive. Nests were considered successful when at least one nestling fledged, and were considered preyed upon when eggs or nestlings disappeared from the nest before the expected time. Nests were considered abandoned when eggs did not hatch at the expected time and were not warm, or when nestlings were found dead in the nest without signs of predation. Some nests were destroyed by natural causes, such as rain, tree fall or land slide.

The exact location of the nest was registered and observed for previous utilization during the same or during the previous reproductive season. We considered a nest site to be reused (nest site reuse) when an active nest was found at the same site of a previous active nest (that is, nest near the same tree branch, tree trunk, or ravine bed) by the same species. Nest-site reuse was considered independent of old nest reutilization. Nests were considered reused when old nests were reutilized in a subsequent breeding attempt. In some cases, the old nest structure was used only as a support for the new nest, which was built with new material. In these cases, nests were considered new nests (nest atop) in spite of being nest site reuse cases. Old nest material was identified by dull coloration. Nest sites reused during the same breeding season consisted of reusing the same nest structure in all cases. Nest site reuse between some years was usually characterized by a new nest being built in the same nest site. There were two exceptions of nest reuse between consecutive years by $L$. amaurocephalus and two by L. euleri. In order to test for associations between reproductive success and the reuse of a nest/nest site, we did not consider nests whose previous fate could not be determined. Since a nest necessarily belongs to a nest site, all nest reuse cases were also nest site reuse cases; however, not all nest site reuse cases were also nest reuse cases. All cases of reuse were carried by individuals of the same species that had previously used that nest or nest site, although the identity of individuals and pairs involved in previous and subsequent nesting attempts was not known.

\subsection{Data analysis}

Chi-square and Fisher Exact tests were used to evaluate the association of nest reuse with nest fate and were conducted using Statsoft (1995). Yates correction for continuity was used for Chi-square tests with one degree of freedom. The percentage of the nest site turnover (movement to a new site between some years) of nest sites not used in two consecutive years was calculated using the formula provided by Erwin (1978 apud Burger, 1981):

$\mathrm{T}=1 / 2\left(\left(\mathrm{~S}_{1} / \mathrm{N}_{1}\right)+\left(\mathrm{S}_{2} / \mathrm{N}_{2}\right)\right)$,

where: $S_{1}=$ number of nest sites used only in year one, $\mathrm{S}_{2}=$ number of nest sites used only in year two, $\mathrm{N}_{1}=$ total number of nests sites used in year one, $\mathrm{N}_{2}=$ total number of nests sites used in year two. This rate does not exceed 1 and can be computed as a percentage (Burger, 1981). For this analysis, we only considered nest sites monitored during two consecutive years.

\subsection{Species}

All three species studied are flycatchers (Tyrannidae). Leptopogon amaurocephalus build closed, globular nests attached to roots under ravine banks or (rarely) to roots of fallen trees. Nests can usually be found along streams and dirt roads, although it may rarely be found inside forests (Simon, 1997; Aguilar, 2001). It is considered to be monogamous, but its mating system has not been studied in detail. It is an insectivore species and lays two or three eggs per clutch, which are synchronously incubated. Both parents feed nestlings (Sick, 1997; Simon, 1997; Aguilar, 2001).

Lathrotriccus euleri is also a monogamous species, which builds open nests in cavities of large structures, such as banks or tree trunks (Sick, 1997; Aguilar et al., 1999). It is also an insectivore, lays two or three eggs, 
and both parents feed nestlings. Eggs are also synchronously incubated (Sick, 1997; Aguilar et al., 1999).

Mionectes rufiventris also builds closed nests under ravine banks and we did not find nests in other substrates in our study site (Aguilar et al., 2000). It is partly frugivorous and establishes leks (Bencke,1995; Sick, 1997; Pizo and Aleixo, 1997). Females build the nest and take care of eggs and nestlings alone. It lays two or three eggs, incubated at the same time (synchronously) (Benke, 1995; Sick, 1997; Pizo and Aleixo, 1997; Aguilar et al., 2000).

\section{Results}

No nests were found in the smallest fragment. With the exception of two nests, all nests were found along streams and treefalls, where nests of the studied species had not been previously reported. During most years, nest searches began in June, but in 1998 it was done all year round. New nests were found still being built in late August and nests with eggs occurred between September and December. 134 nests were found and monitored: 68 of Leptopogon amaurocephalus, 40 of L. euleri and 26 of M. rufiventris.

Eleven (16.2\%) nests of L. amaurocephalus and one (2.5\%) nest of L. euleri were reused during the same reproductive season. Eggs were found laid for the first time between 15 and 23 September, 1998 and predated between 2 and 5 October in the L. euleri nest, and two new eggs were laid about 21 October and were successful.

Fourteen $(53.8 \%)$ nest sites of L. amaurocephalus were reused during consecutive breeding seasons and three $(11.5 \%)$ were reused during non-consecutive breeding seasons. For L. euleri, 10 (71.4\%) nest sites were reused during consecutive breeding seasons and three (21.4\%) were reused in non-consecutive breeding seasons. Only two $(9.5 \%)$ nesting sites of $M$. rufiventris were reused during consecutive breeding seasons and three $(14.3 \%)$ were reused in non-consecutive breeding seasons.

Nest site reuse was not associated to the fate of the previous nest for any of the three species: L. amaurocephalus $\left(\chi^{2}\right.$ with Yates correction $\left.=2.00 ; \mathrm{df}=1 ; \mathrm{p}=0.16\right)$, L. euleri $\left(\chi^{2}\right.$ with Yates correction $\left.=0.94 ; \mathrm{p}=0.33\right)$ and M. rufiventris (Fisher Exact Test; $\mathrm{p}=0.53$ ).

Nest site turnover rates varied among the three species. Leptopogon amaurocephalus had the lowest (34\%) mean turnover rate $(0.34 \pm 0.21, \mathrm{n}=4)$ representing a high nest site reuse over the four seasons analyzed. For this species, the turnover rate varied strongly, from 9 to $52 \%$. Lathrotriccus euleri had an intermediate (66\%) mean turnover rate $(0.66 \pm 0.09, \mathrm{n}=4)$ and a smaller variation among years, whereas $M$. rufiventris had a very high $(92 \%)$ mean turnover rate $(0.92 \pm 0.11, \mathrm{n}=4)$, and thus a low nest site reuse.

\section{Discussion}

It is hypothesized that the reuse of nesting site is related to previous successful nesting attempts in the same site, a behavior that would be favored by natural selection
(Blancher and Robertson, 1985; Gavin and Bollinger, 1988; Gauthier, 1990), and is supported by empirical evidence (Harvey et al., 1979; Hepp and Kennamer, 1992, Thorstrom et al., 2001; Styrsky, 2005). In our study, however, reuse of nest sites was not related to the fate of previous nesting attempts at that site. Alternatively, this nest site reuse might be related to high nest site fidelity, which has been described for migratory species as a philopatric tendency of adults to return to the nesting site (Harvey et al., 1979).

The reuse of old nests as a support for new nests was observed twice for L. euleri and L. amaurocephalus. For L. amaurocephalus, the same structure was reused only once for two consecutive breeding seasons. The low reuse rate of nest structures between some years is probably related to its dismemberment and wearing, since very few nests remain in good conditions between breeding seasons. Whenever possible, however, it would be beneficial to reuse successful old nest structures as it would reduce time and energy spent in nest building while maintaining a high quality nesting site. Still, reuse of old nests may have associated costs, such as the presence of parasites in the nest and the fragility of nest structure (Barclay, 1988; Curson et al., 1996; Bergin, 1997; Friesen et al., 1999). In the tropics, Oniki and Willis (2003) registered nest reuse (or utilization of the old nest as a support for new nests) by the same specie in various species.

Nest/nest site reuse was unrelated to nest success in the previous breeding attempt for all three studied species. This is contrary to the positive association between the reuse of nesting sites and the success of the previous breeding attempt described for various other species (Harvey et al., 1979; Blancher and Robertson, 1985; Gavin and Bollinger, 1988; Gauthier, 1990; Hepp and Kennamer, 1992). Alternative explanations for this lack of relationship may include scarcity or high overall quality of available nesting sites. Furthermore, other advantages of reusing nesting sites include previous knowledge of local predators, availability of food or competitors (Hepp and Kennamer, 1992; Linderg and Sendinger, 1997; Reed et al., 1998).

Our results indicate that there is a tendency for low turnover in nesting sites throughout the years. Only $M$. rufiventris differed from this tendency, showing high turnover rates and few nest reuse cases. Harvey et al. (1979) considered as nest site reuse, nests placed up to $50 \mathrm{~m}$ away from the nest site used in the previous breeding season. In spite of the high rate of nest or nest site reuse, it was not possible to determine if nest reuse is conducted by the same individuals since we had few banded birds using monitored nests. Simon (1997) observed that in L. amaurocephalus, at least one member of the pair in a given breeding season stayed at the nest/nest site for the next year, but Oniki and Willis (2003) registered $L$. amaurocephalus nest site reuse by $M$. rufiventris. In our study area, most banded birds stayed for at least two breeding seasons in the same area, and it was possible to see the adults in the nest and in several visits to the nest. 
Nest and nest site reuse has been registered for several species in Brazil (Oniki and Willis 2003), but the understanding of this behavioral pattern depends on further studies, including experimental manipulation of availability and quality of nests and nesting sites.

Acknowledgments - We would like to thank CNPq for a research grant and a Research Fellowship to MÂM, and for a Student Fellowship to TMA. We are grateful to COPASA-MG for allowing this study on their areas. The following colleagues helped during data collection: M. Anciães, R. D. Andrade, L. Guimarães, L. O. Leite, M. Maldonado-Coelho and F. Sebaio. We are grateful to M. Anciães, R. P. Martins and R. Maia for criticizing previous drafts of the manuscript.

\section{References}

AGUILAR, TM., LEITE, LO. and MARINI, MÂ., 1999. Biologia da nidificação de Lathotriccus euleri (Cabanis 1968) (Tyrannidae) em fragmentos de mata de Minas Gerais. Ararajuba, vol. 7, no. 2, p. 125-133.

AGUILAR, TM., MALDONATO-COELHO, M. and MARINI, MÂ., 2000. Nesting biology of the Gray-hooded Flycatcher (Mionectes rufiventris). Ornit. Neotr., vol. 11, p. 223-230.

AGUILAR, TM., 2001. Biologia reprodutiva e seleção de habitat por L. amaurocephalus (Aves, Tyrannidae), em fragmentos de Mata Atlântica em Minas Gerais - MS. 106p. (Dissertação de Mestrado) - Belo Horizonte, UFMG, Minas Gerais.

BARCLAY, RMR, 1988. Variation in the costs, benefits, and frequency of nest reuse by Barn Swallows (Hirundo rustica). Auk, vol. 105, p. 53-60.

BENCKE, GA., 1995. The nest of the Grey-headed Flycatcher Mionectes rufiventris. Bull. B. O. C., vol. 115, n. 2, p. 105-107.

BERGIN, TM., 1997. Nest reuse by Western Kingbird. Wilson Bull., vol. 109, no. 4, p. 735-737.

BLANCHER, PJ. and ROBERTSON, RJ., 1985. Site consistency in Kingbird breeding performance: implications for site fidelity. J. Anim. Ecol., vol. 54, no. 3, p. 1017-1027.

BURGER, J., 1981. Effects of human disturbance on colonial species, particularly gulls. Colonial Waterb., vol. 4, p. 28-36.

CETEC, 1993. Desenvolvimento de metodologia para recuperação do revestimento florístico natural em áreas de proteção das captações de água da COPASA na região metropolitana da grande Belo Horizonte. Belo Horizonte: SAT/ CETEC, 83p.

CURSON, DR., CHRISTOPHER, CB., and MATHEWS, NE., 1996. Nest-site reuse in the Western Wood-Peewee. Wilson Bull., vol. 108, no. 2, p. 378-380.
FRIESEN, LE., WYATT, VE., and CADMAN, MD., 1999. Nest reuse by Wood Thrushes and Rose-breasted Grosbeaks. Wilson Bull., vol. 111, no. 3, p. 132-133.

GAUTHIER, G., 1990. Philopatry, nest-site fidelity, and reproductive performance in Buffleheads. Auk, vol. 107, no. 1, p. $126-132$.

GAVIN, TA. and BOLLINGER, EK., 1988. Reproductive correlates of breeding-site fidelity in Bobolinks (Dolichonyx oryzivorus). Ecology, vol. 69, no. 1, p. 96-103.

HARVEY, PH., GREENWOOD, PJ. and PERRINS, CM., 1979. Breeding area fidelity of Great Tits (Parus major). J. Animal Ecol., vol. 48, no. 1, p. 305-313.

HEPP, GR. and KENNAMER, RA., 1992. Characteristics and consequences of nest-site fidelity in Wood Ducks. Auk, 109, no. 4 , p. $812-818$.

LINDBERG, MS. and SEDINGER, JS., 1997. Ecological significance of brood-site fidelity in Black Brant: spatial, annual, and age-related variation. $A u k$, vol. 115, no. 2, p. 436-446.

ONIKI, Y. and WILLIS, EO., 2003. Re-uso de ninhos por aves neotropicais. $A O$, no. 116, p. 4-6.

PICHORIM, M., BORNSCHEIN, MR., and REINERT, BL., 1996. Aspectos da biologia reprodutiva de Knipolegus nigerrimus (Tyrannidae). Ararajuba, vol. 4, no. 1, p. 29-31.

PIZO, MA. and ALEIXO, A., 1997. Lek behavior of the Grayhooded Flycatcher. Condor, vol. 100, no. 4, p. 726-731.

REED, ET., COOCH, EG., GOUDIE, RI. and COOKE., F., 1998. Site fidelity of Black Brant wintering and spring in the strait of Georgia, British Columbia. Condor, vol. 100, no. 3, p. $426-437$.

SICK, H., 1997. Ornitologia Brasileira. Rio de Janeiro: Ed. Nova Fronteira, 862p.

SIMON, JE., 1997. Descrição e análise do padrão de nidificação de Leptopogon amaurocephalus Tschudi, 1846 (Aves, Tyrannidae) na Zona da Mata de Minas Gerais - MS 74p. (Dissertação de Mestrado) - Rio de Janeiro, UFRJ, Rio de Janeiro.

STATSOFT, INC., 1995. STATISTICA for Windows [Computer program manual]. Tulsa, OK.

STYRSKY, JN., 2005. Influence of predation on nest-site reuse by an open-cup nesting neotropical passerine. Condor, vol. 107, no. 1 , p. 133-137.

THORSTROM, R., MORALES, CM. and RAMOS, JD., 2001. Fidelity territory, nest site and mate, survivorship, and reproduction of two sympatric forest-falcons. J. Raptor Res., vol. 35 , no. 2 , p. $98-106$. 